IZA DP No. 7793

Impact of Duration of Primary Education on

School Outcomes: A Cross-Country Analysis

Luis Diaz-Serrano

Jessica Pérez-Reynosa

December 2013 


\title{
Impact of Duration of Primary Education on School Outcomes: A Cross-Country Analysis
}

\author{
Luis Diaz-Serrano \\ CREIP, Universitat Rovira i Virgili \\ and IZA \\ Jessica Pérez-Reynosa \\ CREIP, Universitat Rovira i Virgili
}

Discussion Paper No. 7793

December 2013

\author{
IZA \\ P.O. Box 7240 \\ 53072 Bonn \\ Germany \\ Phone: +49-228-3894-0 \\ Fax: +49-228-3894-180 \\ E-mail: iza@iza.org
}

\begin{abstract}
Any opinions expressed here are those of the author(s) and not those of IZA. Research published in this series may include views on policy, but the institute itself takes no institutional policy positions. The IZA research network is committed to the IZA Guiding Principles of Research Integrity.

The Institute for the Study of Labor (IZA) in Bonn is a local and virtual international research center and a place of communication between science, politics and business. IZA is an independent nonprofit organization supported by Deutsche Post Foundation. The center is associated with the University of Bonn and offers a stimulating research environment through its international network, workshops and conferences, data service, project support, research visits and doctoral program. IZA engages in (i) original and internationally competitive research in all fields of labor economics, (ii) development of policy concepts, and (iii) dissemination of research results and concepts to the interested public.
\end{abstract}

IZA Discussion Papers often represent preliminary work and are circulated to encourage discussion. Citation of such a paper should account for its provisional character. A revised version may be available directly from the author. 


\section{ABSTRACT \\ Impact of Duration of Primary Education on School Outcomes: A Cross-Country Analysis*}

Using panel data for non-OECD countries covering the period 1970-2012, this paper analyzes the impact of the duration of primary education on school enrollment, drop-outs and completion rates. The empirical results show that for children in elementary school one additional grade of primary education has a negative impact on enrollment rate, while the effect on drop-outs is positive. Analogously, we also observed that an additional grade in primary education reduces the enrollment rate in secondary education. These results are in line with the fertility model approach; that is, in developing and underdeveloped countries parents do not have incentive to send children to school given the high perceived present economic value of children.

JEL Classification: I21, I25, I28

Keywords: primary education, school achievement, political institutions, educational reforms

Corresponding author:

Luis Diaz-Serrano

Department of Economics

Universitat Rovira i Virgili

Avinguda de la Universitat 1

43204 Reus

Spain

E-mail: luis.diaz@urv.cat

\footnotetext{
* We acknowledge the financial support from the Spanish Ministry of Economy and Competitiveness (grant \#ECO2010-20829).
} 


\section{Introduction}

The acquisition of education is a significant and indivisible investment, where individuals incur costs at the present time in return for rewards in the future. Consequently, individual schooling attainment is largely constrained by family resources and influenced by factors affecting the costs and benefits to households of sending children to school. For developing and underdeveloped countries, parental preferences play a crucial role in these schooling decisions, since families have to choose between sending children to work or keeping them in the school (Bursztyn and Coffman, 2012). Hence, costs to the family include not only the direct costs of school attendance but also the opportunity cost, namely, foregone earnings of time spent in school instead of in alternative productive activities.

Since, mainly in developing countries, the relative costs incurred by families can constitute an impediment for acquiring education because of the presence of borrowing constraints, empirical evidence suggests a direct link between schooling costs and school attendance. For example, some of this evidence eport dramatic increases in school enrollment with initiatives to eliminate school fees (Kremer, 2003) and to reduce costs associated with accessing schooling (Kremer et al. 1997; Duflo, 2001). However, to the best of our knowledge, previous studies do not pay attention to the implications of the opportunity cost, which is an important factor influencing the decision to send children to school, specially in developing countries. ${ }^{1}$ One reason why families might choose not to send children to school is a low perceived return of attending school (Edmonds and Pavcnik, 2005).

\footnotetext{
${ }^{1}$ The literature analyzing the impact of the opportunity cost is mainly focused on high school graduates who face the decision to enroll in college or get a job (Hansen, 1963; Catsiapis, 1987; Cameron and Taber, 2004). Therefore, students are the ones who plan their investment in education, contrary to what is considered in this paper where parents are the decision makers.
} 
In this context, an increase in the duration of primary education makes enrollment decisions more difficult for parents and foregone earnings have a greater say in the decision. Educational reforms that a government can carry out in order to delay leaving school can be translated into both an increase in direct expenditures on tuition, books or transportation, and in the opportunity cost by staying an extra year in primary school; this especially affects students in the age of attending compulsory school that may have the option to work. Thus, a reform in the number of years an individual must spend in the school system could imply an increase in the drop-out rate (or decrease in school enrollment in the following educational level, i.e., secondary), since an additional year not only involves a greater allocation of education resources from the government but also by families. On the one hand, schools are required to deal with a significantly enlarged student body and this can create logistical problems with staff and classroom numbers. On the other hand, families "lose" another economically active member for an additional year. The latter is especially problematic if family income is near to subsitence level. Although this is an extremely important issue, as far as we are aware there is no previous empirical evidence on the impact of this type of reform on educational outcomes in depeloping and underdeveloped countries.

Considering that from a empirical point of view little is known about the extent to which a reform of the number of years (grades) of schooling could have an impact on education in terms of attendance for primary and secondary school, the aim of this paper is to evaluate the impact of the duration of primary education, which is compulsory in most countries, on school enrollment, graduation and drop-out rates. We use enrollment rates because student attendance in school is a key indicator of whether countries or regions are improving educational systems and because student attendance is a good proxy for measuring school quality. 
In our study we exclude developed countries since they use other mechanisms in order to avoid drop-outs and parent's decision of sending children to school is based on different criteria than that of developing and underdeveloped countries, where child labor is more common. We focus on developing and underdeveloped countries where the context is different and the opportunity cost for families can be substantial because most working children are employed by their parents (especially in rural areas) rather than in manufacturing establishments or other forms of wage employment (Edmonds and Pavcnik, 2005). Furthermore, empirical evidence supports the importance of borrowing constraints for developing countries affecting children's progression through the primary school system and causes them to withdraw from school earlier (Jacoby, 1994). Although education is compulsory and free for almost all children, the law in these countries is loosely enforced. ${ }^{2}$

Using cross-country panel data covering the period 1970-2012, we find that for children in elementary school, one additional grade of primary education has a negative impact on enrollment rate, while the effect on drop-outs is positive. We also observe that an additional year (grade) in primary education reduces the enrollment rate in secondary education. These results are in line with fertility models and indicate that families in developing and underdeveloped countries do not have incentive to educate their children, because they need them for providing resources to the household. In this context, policies consisting of increasing the duration of primary education may not have the same desirable effect as in developed countries. In developing and underdeveloped countries, where families face severe borrowing constraints, children represent a

\footnotetext{
${ }^{2}$ For instance, in Brazil "...Although working is only legal at the age of 16 , over 15 percent of 15 -year-old children from the bottom quartile households in the income distribution were not enrolled in school in 2006, and over 22 percent reported having a job during the week they were interviewed for the 2006 PNAD..." Bursztyn and Coffman (2012).
} 
high economic value; therefore, families prefer to send children to work and to gain from their earnings rather than investing in their education. Although previous literature provides evidence that increasing compulsory schooling in developed countries has positive returns in terms of earnings and non-pecuniary outcomes (school externalities), this may not apply to developing and underdeveloped countries where children earnings are one component of the household income and in many cases represent the support of the entire family.

The rest of the paper is structured as follows. The next section provides the conceptual framework of our study. Section 3 presents an overview of related literature. Section 4 describes the econometric strategy and data. Section 5 presents the empirical results. Finally in Section 6, we discuss our main findings.

\section{Conceptual Framework}

Schooling decisions occur largely while the person is still a child and living with his or her parents. From the theoretical point of view, the standard approach for schooling decisions considers either a single decision-maker, parents making the decision for their children or dynasties with unified utility functions. Ota and Moffatt (2007) identify three broad approaches to the modeling of the determinants of children's schooling: human capital investment model, demographic models and fertility decision models.

The first approach is the human capital investment model. In this model, parents are assumed to make the decision by maximizing their lifetime utility which depends on consumption in two 
periods, subject to an inter-temporal budget constraint. ${ }^{3}$ This model is often used to explain the lower school enrollment for girls compared to boys (see Psacharopoulos and Woodhall, 1985; Haddad et al., 1997). Since the choice between schooling and work is assumed to be made by an individual agent, the effect of the household situation, particularly those of an individual child's position within the household, are not fully taken into account.

The second approach is that of demographic models. These models establish a link between the demographic characteristics of a child (e.g., number of siblings, birth order) and their educational attainment (as measured by test scores, completed years of schooling or earnings). In these models, two theories are tested. The first is the "resource dilution effect" which predicts that the more children there are in the household, the lower the educational achievements, since the resources of the household, in terms of both material resources and parents' attention, are diluted. The second theory, the "teaching effect," predicts that the presence of siblings has a positive influence on educational achievement through the benefit of either teaching younger siblings or being taught by older siblings. Empirical studies, which include the number of children in the household as an explanatory factor, tend to support the resource dilution effect, which is also suggested by the fertility decision model. However, when birth order is included as a variable, the results are mixed for both resource dilution and teaching effects (see Kessler, 1991; Travis and Kohli, 1995). Using data from Peru, Patrinos and Psacharopoulos (1997) find that having a greater number of younger siblings implies less schooling, more age-grade distortion in the

\footnotetext{
${ }^{3}$ In the first period, they either invest in children's education or send them to work and gain from their earnings. In the second period, parents become economically inactive and rely on the economic support of their children, whose incomes depend on educational level.
} 
classroom and more child labor. See related studies by Knodel et al., (1990) and Knodel and Wongsith (1991) for more information. ${ }^{4}$

The third approach, fertility decision model, is precisely the conceptual framework we adopt in this paper. This model is based on household production models and assumes that high fertility in developing countries results from the high perceived economic value of children and investigates what drives a transition in parents' preference of children. Following this theoretical contribution, some empirical work has been undertaken. These studies typically examine a household's joint decision on how many children to have; how children's time is allocated between schooling, wage work and family work; and how resources are distributed among household members (see e.g., De Tray, 1980; Mueller, 1984). This approach can be used to identify what types of household are more likely to choose to educate their children, particularly in the case of schooling choices in rural areas. Our paper can be framed in this third approach.

\section{Literature Review}

A large literature investigates the causal effect of years of compulsory schooling (either primary or secondary) on pecuniary and non-pecuniary outcomes. Using compulsory laws as an instrument to analyze this effect, several papers have consistently documented gains to adult outcomes from an additional year of schooling in developed countries. In terms of earnings, Angrist and Krueger (1991) and Acemoglu and Angrist (2001) using data from the United States (U.S.), estimate that annual adult earnings are about 10 percent higher for students compelled to stay a year longer in compulsory education. Harmon and Walker (1995) and Oreopoulos (2006)

\footnotetext{
${ }^{4}$ This literature is framed into the demographic approach.
} 
find about 14 percent higher earnings from school compulsion in the United Kingdom. Regarding non-pecuniary outcomes (schooling externalities), Lochner and Moretti (2004) estimate that compulsory schooling in the U.S. lowers the likelihood of committing a crime or ending up in jail. Black et al., (2004) find that compulsory schooling reduces the chances of teen pregnancy in the U.S. and Norway. Meanwhile, Lleras-Muney (2005) estimates an additional year of compulsory schooling increases the age of death mong elderly people in the United States.

Despite the fact that there is extensive literature that addresses the issue of the impact of an additional year of schooling on future outcomes in the long-run (earnings or lifetime wealth), previous papers have not yet considered the short-term effect of school attendance and drop-outs. As far as we are aware, this paper is the first to analyze the potential effect of the changes in the duration of primary education on school enrollment, graduation and drop-out rates. ${ }^{5}$

Since education involves an investment decision, an additional year of schooling implies some cost for both, families and the government. Empirical research in this field links schooling decisions with both direct and indirect costs of sending children to school. As pointed out earlier, the direct costs of schooling include school fees, books, uniforms and commuting costs. Some studies have found a direct link between these directs schooling costs and school attendance. Kremer et al., (1997) evaluate a randomized intervention in Kenya providing uniforms to students who would otherwise need to pay for uniforms. After five years, students with the free uniforms had completed $15 \%$ more schooling than their counterparts without free uniforms. Also, the dropout rate was $6.8 \%$ at program schools, and $16.5 \%$ in comparison schools. The analysis suggests

\footnotetext{
${ }^{5}$ Most related to our work, Krashinsky (2006) studies the effect of elimination of the fifth year of high school in Ontario, Canada on academic performance in first-year university courses. He finds that cohorts with four years of high school had substantially lower grade point averages in college than those who attended high school for five years.
} 
that reducing school fees would reduce drop-out rates. In a related study, Deininger (2003) evaluates the impact of a "Universal Primary Education" program in Uganda which dispensed with fees for primary enrollment. He finds that a dramatic increase in primary school attendance and a substantial reduction in inequalities in attendance related to gender, income, and region were associated with the program.

The indirect schooling costs, such as the costs associated with accessing schooling, may also be important. Duflo (2001) finds a large increase in schooling attainment accompanying a school construction program in Indonesia that would have dramatically lowered the commuting costs of schooling. In Mexico, Schultz (2004) examine the impact of school enrollment of a school subsidy program in poor rural communities in Mexico called Progresa. He finds an average increase in enrollment of $3.4 \%$ for all students in grades 1 through 8 ; the increase was largest among girls who had completed grade 6 , at $14.8 \% .^{6}$

To our understanding, an indirect cost, as foregone income of the child while going to school, is one of the main important costs that families face in developing and underdeveloped countries. Households may also be forced to keep children away from school because their income is close to subsistence level. In Becker's (1965) model of household production and consumption, and the opportunity cost of an individual's time is the marginal value of his or her output in alternative valued activities at home or family business, such as farming. Thus, for these families, if the net return to human capital investment is too low compared to investment in other assets, children may be sent to work instead of attending school. According to this, as we hypothesize in this paper, one additional grade level in primary education may increase school dropouts. Jacoby

\footnotetext{
${ }^{6}$ See Kremer (2003) for a summary of evaluations of educational programs in developing countries.
} 
(1994) investigates the effect of borrowing constraints by looking at how quickly children, with different family backgrounds, progress through the primary school system in Peru. In his model children from very high income households or with very low (initial) opportunity costs attend school full-time for essentially their entire educational careers. But, children with a high opportunity cost relative to household income may start school with only part-time attendance. Jacoby (1994) empirically finds that children start withdrawing from school earlier in households with lower incomes and durable good holdings and when children are more closely spaced.

\section{Empirical Strategy and Data}

\subsection{Empirical Model}

To evaluate and test the link between the duration of primary education and various educational outcomes such as school enrollment and drop-outs rate, we use panel data of non-OECD countries covering the period of 1970-2012 and estimate the following linear model:

$$
y_{i t}=\alpha+\operatorname{DUPRIM}_{i t} \gamma+\mathrm{X}_{i t} \beta+\mu_{i}+\varepsilon_{i t}
$$

where $y_{i t}$ is the educational outcome in country $i$ at time $t ; X_{i t}$ is a matrix containing a set of covariates; $\mu_{i}$ is a country's fixed-effect that allows us to control for a country's unobserved heterogeneity (such as history and culture that might affect global macro-trends (e.g., rising levels of educational attainment)); $\varepsilon_{i t}$ is a time-varying error term, and $\alpha, \gamma$ and $\beta$ are a set of parameters to be estimated. DURPRIM ${ }_{i t}$ refers to the duration of primary education in country $i$ at time $t$. In 
this equation, our main coefficient of interest is $\gamma$, which picks-up the effect of the duration of primary education on the level of enrollment and drop-outs. Equation 1 is estimated using a linear fixed-effect panel data model.

Since we are primarily interested in analyzing the impact of policies changing the duration of primary education, we also consider temporal changes in the level of these outcomes and inputs. Equation 2 explains the impact of reforms aimed at changing the duration of primary education on educational outcomes of the population:

$$
\Delta y_{i t}=\alpha+y_{i, t-1} \delta+\Delta D U P R I M_{i t} \gamma+\Delta \mathrm{X}_{i t} \beta+\mu_{i}+\varepsilon_{i t}
$$

In both equations, our outcome variables $\left(y_{i t}\right)$ are the school enrollment rate in primary and secondary education, and the completion rate and drop-outs rate in primary education. In Equation 2, we include the endogenous variable lagged one period $\left(y_{i, t-1}\right)$ since the speed of growth in the explained variable depends on the level of this variable the previous year, i.e, those countries that have higher enrollment rates at $t-1$ will grow at a lower rate from $t-1$ to $t$.

By construction, $y_{i, t-1}$ is correlated with the error term, which generates a severe problem of endogeneity. In addition, the estimation of Equation 2 may present other econometric problems such as the country-specific effect and the presence of non-strictly exogenous variables. In order to overcome these problems, the strategy used to estimate equation (2) is the following. First, as in the fixed-effects model, we first difference equation (2) in order to remove the country-specific effect $\mu_{i}$. However, differencing means that even strictly exogenous variables can become 
endogenous, in addition to the presence of non-strictly exogenous variables. Therefore, our core specifications will include not only correlated and heteroskedastic residuals, but also non-strictly exogenous and endogenous variables as covariates. In this context, a fixed-effects model with the Newey-West corrected covariance matrix provides consistent estimates of the standard errors in the presence of serial correlation and heteroskedasticity in the residuals. However, the presence of endogenous covariates creates severe identification problems in the econometric estimation that in turn lead to inconsistent estimates of the model. To deal with this problem, we use a variant of the Arellano and Bond (1991) Generalized Method of Moments (GMM) estimator. More specifically, we compute a two-step GMM estimator which provides consistent and robust parameters to heteroskedasticity and serial correlation. ${ }^{7}$ However, the two-step estimator computes standard errors that are downward bias. In order to fix this, we apply the finite-sample correction of the two-step covariance matrix proposed in Windmeijer (2005).

The consistency of the GMM estimator depends on whether the lagged values of the explanatory variables are valid instruments in the regression and the error term is not serially correlated. The validity of these assumptions is addressed by using different specification tests. For the validity of the instruments, we use the Hansen test of over-identifying restrictions where the null hypothesis is the joint validity of the instruments. ${ }^{8}$ The Hansen $\mathbf{J}$ statistic replaces the Sargan test used in the original one-step Arellano-Bond estimator, since the Hansen test is robust to heteroskedasticity and autocorrelation. ${ }^{9}$ In order to test the hypothesis of the absence of first and second-order serial correlation in the first differenced residuals, we use the Arellano-Bond test for autocorrelation.

\footnotetext{
${ }^{7}$ See Roodman (2009) for details.

${ }^{8}$ Under the null hypothesis the statistic follows a chi-square where the degrees of freedom are determined by the number of instruments used in the estimation.

${ }^{9}$ See Roodman (2009) for details.
} 


\subsection{Data}

The empirical analysis draws on a variety of datasets. We assemble a database that contains information on a population's educational attainment at country level, income per capita and other country characteristics. We use World Bank data which provides various measures on educational outcomes (completion rates, drop-outs and enrollment rates) at the country level, per capita income and composition of the population. ${ }^{10}$ Polity IV data provides a measure of democracy.

Our outcome variables are completion, drop-out and enrollment rates which are useful for comparative research. Primary Completion Rate $(P C R T)$ is the total number of new entrants in the last grade of primary education, regardless of age, expressed as a percentage of the total population of the theoretical entrance age to the last grade of primary education. ${ }^{11}$ Drop-out rate in primary school is the students or pupils who leave school definitively in a given school year, as a percentage of all students enrolled in primary school.

Gross enrollment ratios are defined as the total number of children enrolled in a level (primary or secondary education), regardless of age, divided by the population of the age group that officially corresponds to the same level. Gross enrollment ratios can exceed one-hundred percent due to the inclusion of over-aged and under-aged students because of early or late school entrance and grade repetition. Net enrollment ratios are calculated as the ratio of children of official school age who

\footnotetext{
${ }^{10}$ Education data comes from wbopendata available in Stata developed by Azevedo (2011).

${ }^{11}$ The ratio can exceed one-hundred percent due to over-aged and under-aged children who enter primary school late/early and/or repeat grades.
} 
are enrolled in a particular educational level (primary or secondary education) to the total population of the same age group.

We considered the following covariates: Duration of primary is the number of grades (years) required to complete primary education. This is our variable of interest. As controls for country characteristics we include the level of the GDP per capita lagged one period, and its annual growth. These two variables allow us to control for differences in income across countries. Following previous authors, we also include a measure of Democracy, which is a dummy variable (Persson and Tabellini, 2009; Besley et al., 2011). Finally, as a control for urban bias of access to education, we include the percentage of urban population. We include this control since children living in rural areas are less likely to be enrolled in school (Deininger, 2003). Table 1 (see Appendix) contains the description of the outcome variables and the explanatory variables used in this work.

[Insert table 1 here]

Table 2 shows summary statistics of these variables. In our sample of non-OECD countries, on average, the primary completion rate is $73.22 \%$ and the drop-out rate is about $34.40 \%$. Net and gross enrollment rate in primary education are $94.74 \%$ and $79.62 \%$, respectively. For secondary education, the net enrollment rate is, on average, $53.19 \%$ and the gross enrollment is $51.97 \%$. The duration of primary education is about 6 years. In about $41 \%$ of the country-year observations the regime is democratic. On average, the percentage of urban population is about $46 \%$.

[Insert table 2 here] 


\section{Results}

Table 3 reports the results of the estimation of our core model in levels (Equation 1) for all our educational outcomes. This model is estimated using a linear panel fixed-effect model. We start by discussing the results of our explanatory variable of interest, that is, duration of primary education. We observe that the parameter associated with this variable is statistically significant and negative for the primary completion rate and positive for the primary drop-out rate. This result indicates that in countries where duration of primary education is longer, the completion rate in primary education is lower, and hence the drop-out rate is higher. Regarding secondary education, we find that the link between duration of primary education and enrollment rate is statistically significant and negative, which means that in those countries where duration of primary education is longer, the enrollment rate in secondary education (gross and net) is lower. As will be explained later, these findings are in line with the fertility model approach mentioned in Section 2.

[Insert table 3 here]

The remaining covariates behave according to expectations. That is, those factors that are positively linked with enrollment and graduation rates show a negative relationship with dropouts. We observe that in those countries where the GDP per capita is higher, the completion rate for primary education and the enrollment rate in secondary education is also higher; but the drop-out rate is lower. One common hypothesis is that credit constraints limit the investment of the poor in their children's education (Schultz, 2004). Children from very low income households 
or with a high opportunity cost relative to household income may have lower attendance rates wealthier households (Jacoby, 1994). Thus, countries with higher income levels will have higher levels of educational attainment and lower levels of drop-outs.

Similarly, we find that countries with a higher percentage of people living in urban areas have higher levels of completion rates in primary education, as well as higher levels of enrollment in primary and secondary education. This is explained by the fact that people living in rural areas, which may imply higher commuting costs, have limited access to resources and a lower concentration of schools compared to those people in urban areas, where the infrastructure tends to be concentrated. For that reason, a higher percentage of people living in urban areas also implies lower levels of drop-outs in primary education, which is consistent with previous findings on the literature analyzing borrowing constraints and access to school in rural areas where children are employed by their parents to work on the family farm (Schultz, 2004). In countries where the political regimen is democratic, we also observe that completion and enrollment rates in primary education are higher, while the drop-out rate is lower. A common view, is that democratic countries have higher levels of educational attainment compared to non-democratic countries where the educational levels tend to be lower (Lipset, 1959; Barro, 1999; Glaeser et al., 2004)

In Table 4 we report the results of our model in differences (Equation 2). In this table we focus on the impact of reforms on primary education outcomes. We estimate the model using a linear panel fixed-effects model and the Generalized Method of Moments (GMM). We begin by discussing the results of our variable of interest, i.e, the changes in the duration of primary education. Our results indicate that changes in the duration of primary education matters for children's 
educational outcomes. This variable exerts a statistically significant negative impact on the annual growth of completion and enrollment rates in primary education. Analogously, we also observe that the annual drop-out growth significantly increases if one additional grade is added to the existing number of grades (i.e., one extra year) These results remain robust to different specifications and estimation methods.

The remaining covariates also behave according to expectations. An increase in the percentage of urban populations, increases the completion rate in primary education and reduces drop-outs. The growth rate of the logarithm of GDP per capita exerts a statistically significant and positive impact on the growth of completion and enrollment rates in primary education; while the impact on the drop-outs growth rate is negative. The first lag of the our outcome variable has turned out to be significant. This means that laggard countries in term of educational achivement tend to experience a higher growth in educational outcomes. This result is consistent in all the alternative models and specifications.

In models using the GMM estimator, we report the results of the Hansen test of over-identifying restrictions on the validity of the instruments, and the Arellano-Bond test of first and second order autocorrelation. $^{12}$ While autocorrelation of the first order prevails by definition, the null hypothesis of second-order autocorrelation must be rejected in order to get consistent estimators. In all models in Table 4, we find that the validity of the instruments is confirmed in all the specifications. For the autocorrelation test, we observe that $\operatorname{AR}(1)$ structure cannot be rejected in any of the estimated models, while the $\operatorname{AR}(2)$ structure is rejected in all of them. These results

\footnotetext{
${ }^{12}$ The null hypothesis is not an autocorrelation and is applied to the differenced residuals.
} 
indicate that there is no serial correlation between the first-differenced variables used as instruments and the first differences of the residuals $\varepsilon_{i t}$; therefore, they are good instruments.

[Insert table 4 here]

Table 5 presents the results of the estimation of our model in differences (Equation 2) for secondary education. This model explains the impact of changes in the duration of primary education on the enrollment rate of secondary education (gross and net). As in Table 4, we estimate this model using the linear panel fixed-effect model and the Generalized Method of Moments (GMM). Results regarding secondary education are in line with those obtained for primary education, that is, increasing the duration of primary education reduces the gross and net enrollment rates in secondary education. The same reasoning as in the case of primary education applies. However, we consider that for secondary education the effect is easier to interpret because children are closer to the legal age to work, so their economic value is even higher than when they are in the age of attending primary education. As in Table 4, the remaining covariates provide the same quantitative and qualitative results.

In Table 5 we also find that the validity of the instruments is confirmed in all the specifications. Regarding the autocorrelation tests, we observe that $\mathrm{AR}(1)$ structure cannot be rejected in any of the estimated models, while the $\mathrm{AR}(2)$ structure is rejected in all of them. The results of both tests confirm the consistency of the GMM estimation.

[Insert table 5 here] 


\section{Conclusions}

Using panel data for non-OECD countries covering the period of 1970-2012, we analyzed the impact of the duration of primary education on school enrollment, drop-out and completion rates. Our results show that for children in elementary school, one additional grade of primary education has a negative impact on enrollment rate, while the effect on drop-outs is positive. Analogously, we maintain that an additional grade in primary education also reduces the enrollment rate in secondary education. Results stemming from this paper are in line with the fertility model approach, that is, in developing and underdeveloped countries parents do not have incentive to send children to school given the high perceived economic value of children. Thus, an increase in duration of primary education discourages their continuation in the education system. Our results indicate that this reasoning applies to both primary and secondary education.

Although previous literature provides evidence that increasing compulsory schooling in developed countries has positive returns in terms of earnings and non-pecuniary outcomes (school externalities), this will not apply to developing and underdeveloped countries where children's earnings are an important component of the household income and in many cases represent the support of the entire family. Therefore, policies consisting in delaying the completion of primary education, which have proven to be succesfull in developed countries, may fail in developing and underdeveloped countries, since they might have an undesired impact on children's educational outcomes (enrollment, graduation or drop-outs). 


\section{References}

Acemoglu, D. and Angrist, J. (2001). How Large are the Social Returns to Education? Evidence from Compulsory Schooling Laws. NBER Macroannual: 9 - 74, National Bureau of Economic Research.

Angrist, J. D. and Krueger, A. B. (1991). Does Compulsory School Attendance Affect Schooling and Earnings? The Quarterly Journal of Economics, 106(4):979-1014.

Arellano, M. and Bond, S. (1991). Some Tests of Specification for Panel Data: Monte Carlo Evidence and an Application to Employment Equations. The Review of Economic Studies, 58(2):277-297.

Azevedo, J. P. (2011). WBOPENDATA: Stata module to access World Bank databases. Statistical Software Components, Boston College Department of Economics.

Barro, R. J. (1999). Determinants of Democracy. Journal of Political Economy, 107(S6):S158S183.

Becker, G. (1965). A Theory in the Allocation of Household Time and Resources. Economic Journal, 70(299):493- 517.

Besley, T., Montalvo, J. G., and Reynal-Querol, M. (2011). Do Educated Leaders Matter? The Economic Journal, 121(554):205-227.

Black, S. E., Devereaux, P. J., and Salvanes, K. (2004). Fast Times at Ridgemont High? The Effect of Compulsory Schooling Laws on Teenage Births. Technical report, National Bureau of Economic Research.

Bursztyn, L. and Coffman, L. C. (2012). The Schooling Decision: Family Preferences, Intergenerational Conflict, and Moral Hazard in the Brazilian Favelas. Journal of Political Economy, 120(3):359 - 397. 
Cameron, S. V. and Taber, C. (2004). Estimation of Educational Borrowing Constraints Using Returns to Schooling. Journal of Political Economy, 112(1):132-182.

Catsiapis, G. (1987). A Model of Educational Investment Decisions. The Review of Economics and Statistics, 69(1):33-41.

Deininger, K. (2003). Does Cost of Schooling Affect Enrollment by the Poor? Universal Primary Education in Uganda. Economics of Education Review, 22(3):291-305.

Duflo, E. (2001). Schooling and Labor Market Consequences of School Construction in Indonesia: Evidence from an Unusual Policy Experiment. American Economic Review, 91(4):795-813.

Edmonds, E. V. and Pavcnik, N. (2005). Child Labor in the Global Economy. The Journal of Economic Perspectives, 19(1):199-220.

Glaeser, E., La Porta, R., Lopez-de Silanes, F., and Shleifer, A. (2004). Do Institutions Cause Growth? Journal of Economic Growth, 9(3):271-303.

Haddad, L. J., Hoddinott, J., and Alderman, H. (1997). Intrahousehold Resource Allocation in Developing Countries: Models, Methods, and Policy. International Food Policy Research Institute (IFPRI) by Johns Hopkins University Press.

Hansen, W. L. (1963). Total and Private Rates of Return to Investment in Schooling. Journal of Political Economy, 71(2):pp. 128-140.

Harmon, C. and Walker, I. (1995). Estimates of the economic return to schooling for the United Kingdom. The American Economic Review, 85(5):1278-1286.

Jacoby, H. G. (1994). Borrowing Constraints and Progress Through School: Evidence from Peru. The Review of Economics and Statistics, 76(1):pp. 151-160.

Kessler, D. (1991). Birth Order, Family Size, and Achievement: Family Structure and Wage Determination. Journal of Labor Economics, 9(4):pp. 413-426. 
Knodel, J., Havanon, N., and Sittitrai, W. (1990). Family Size and the Education of Children in the Context of Rapid Fertility Decline. Population and Development Review, 16(1):pp. $31-62$.

Knodel, J. and Wongsith, M. (1991). Family Size and Children's Education in Thailand: Evidence from a National Sample. Demography, 28(1):pp. 119-131.

Krashinsky, H. (2006). How Would One Extra Year of High School Affect Academic Performance in University? Evidence from a Unique Policy Change. Manuscript, University of Toronto.

Kremer, M. (2003). Randomized Evaluations of Educational Programs in Developing Countries: Some Lessons. The American Economic Review, 93(2):102-106.

Kremer, M., Moulin, S., Myatt, D., April, R. N., and Walji, S. (1997). The Quality-Quantity Tradeoff in Education: Evidence from a Prospective Evaluation in Kenya. Manuscript, Harvard University.

Lipset, S. M. (1959). Some Social Requisites of Democracy: Economic Development and Political Legitimacy. American Political Science Review, 53(1):69-105.

Lleras-Muney, A. (2005). The Relationship between Education and Adult Mortality in the United States. The Review of Economic Studies, 72(1):189-221.

Lochner, L. and Moretti, E. (2004). The Effect of Education on Crime: Evidence from Prison Inmates, Arrests, and Self-Reports. The American Economic Review, 94(1):155-189.

Oreopoulos, P. (2006). Estimating Average and Local Average Treatment Effects of Education when Compulsory Schooling Laws Really Matter. The American Economic Review, 96(1):152-175.

Ota, M. and Moffatt, P. (2007). The within-household schooling decision: a study of children in rural Andhra Pradesh. Journal of Population Economics, 20(1):223-239. 
Patrinos, H. A. and Psacharopoulos, G. (1997). Family size, schooling and child labor in Peru An empirical analysis. Journal of Population Economics, 10(4):387-405.

Persson, T. and Tabellini, G. (2009). Democratic Capital: The Nexus of Political and Economic Change. American Economic Journal: Macroeconomics, 1(2):88-126.

Psacharopoulos, G. and Woodhall, M. (1985). Education for Development: An Analysis of Investment Choices. A World Bank Publication. Published for the World Bank [by] Oxford University Press.

Roodman, D. (2009). How to Do xtabond2: An Introduction to Difference and System GMM in Stata. Stata Journal, 9(1):86-136.

Schultz, T. P. (2004). School Subsidies for the Poor: Evaluating the Mexican Progresa Poverty Program. Journal of Development Economics, 74(1):199 - 250.

Travis, R. and Kohli, V. (1995). The Birth Order Factor: Ordinal Position, Social Strata, and Educational Achievement. The Journal of Social Psychology, 135(4):499-507. PMID: 7564308.

Windmeijer, F. (2005). A Finite Sample Correction for the Variance of Linear Efficient Two-step GMM Estimators. Journal of Econometrics, 126(1):25 - 51. 


\section{Appendix}

Tabla 1. Variables description.

\begin{tabular}{|c|c|c|c|}
\hline Variables & Description & Source & $\begin{array}{c}\text { Period } \\
\text { Covered }\end{array}$ \\
\hline \multicolumn{4}{|l|}{ Dependent Variables } \\
\hline $\begin{array}{l}\text { Primary Completion } \\
\text { Rate }\end{array}$ & $\begin{array}{l}\text { Percentage of students completing the } \\
\text { last year of primary school. The ratio } \\
\text { can exceed } 100 \% \text { due to over-aged and } \\
\text { under-aged children who enter primary } \\
\text { school late/early and/or repeat grades. }\end{array}$ & $\begin{array}{l}\text { United Nations } \\
\text { Educational, } \\
\text { Scientific, and } \\
\text { Cultural Organization } \\
\text { (UNESCO) Institute } \\
\text { for Statistics. }\end{array}$ & $1970-2050$ \\
\hline Primary Drop-out rate & $\begin{array}{l}\text { Drop-outs in primary school are the } \\
\text { students or pupils who leave school } \\
\text { definitively in a given school year, as a } \\
\text { percentage of all students enrolled in } \\
\text { primary school. }\end{array}$ & $\begin{array}{l}\text { UNESCO Institute for } \\
\text { Statistics. }\end{array}$ & $1970-2011$ \\
\hline $\begin{array}{l}\text { Gross Enrollment Rate } \\
\text { Primary }\end{array}$ & $\begin{array}{l}\text { Total enrollment in primary education, } \\
\text { regardless of age, expressed as a } \\
\text { percentage of the population of official } \\
\text { primary education age. }\end{array}$ & $\begin{array}{l}\text { UNESCO Institute for } \\
\text { Statistics }\end{array}$ & $1970-2050$ \\
\hline $\begin{array}{l}\text { Net Enrollment Rate } \\
\text { Primary }\end{array}$ & $\begin{array}{l}\text { Ratio of children of the official primary } \\
\text { school age who are enrolled in primary } \\
\text { school to the total population of the } \\
\text { official primary school age. }\end{array}$ & $\begin{array}{l}\text { UNESCO Institute for } \\
\text { Statistics }\end{array}$ & $1970-2050$ \\
\hline $\begin{array}{l}\text { Gross Enrollment Rate } \\
\text { Secondary }\end{array}$ & $\begin{array}{l}\text { Total enrollment in secondary } \\
\text { education, regardless of age, expressed } \\
\text { as a percentage of the population of } \\
\text { official secondary education age. }\end{array}$ & $\begin{array}{l}\text { UNESCO Institute for } \\
\text { Statistics }\end{array}$ & $1970-2050$ \\
\hline $\begin{array}{l}\text { Net Enrollment Rate } \\
\text { Secondary }\end{array}$ & $\begin{array}{l}\text { Ratio of children of the official } \\
\text { secondary school age who are enrolled } \\
\text { in secondary school to the population of } \\
\text { the official secondary school age. }\end{array}$ & $\begin{array}{l}\text { UNESCO Institute for } \\
\text { Statistics } \\
\text { f }\end{array}$ & $1970-2050$ \\
\hline
\end{tabular}

\section{Independent Variables}

\begin{tabular}{llll} 
Duration of Primary & $\begin{array}{l}\text { Number of grades (years) required to } \\
\text { complete Primary education. }\end{array}$ & $\begin{array}{l}\text { UNESCO Institute for } \\
\text { Statistics }\end{array}$ & 1970-2050 \\
\hline Democracy & $\begin{array}{l}\text { Dummy that takes value 1 if the } \\
\text { country is democratic. }\end{array}$ & Polity IV data & $1800-2010$ \\
\hline Log (GDP) & Log of per capita income. & World Bank data & $1960-2011$ \\
\hline Urban population(\%) & $\begin{array}{l}\text { Urban population refers to people living United Nations, World } \\
\text { in urban areas as defined by national } \\
\text { statistical offices. }\end{array}$ & $\begin{array}{l}\text { Urbanization } \\
\text { Prospects }\end{array}$ & \\
\hline
\end{tabular}


Tabla 2. Summary Statistics.

\begin{tabular}{|c|c|c|c|c|}
\hline & \multirow{2}{*}{ Mean } & \multicolumn{3}{|c|}{ Std. Dev. } \\
\hline & & overall & between & within \\
\hline \multicolumn{5}{|c|}{ Primary Completion Rate } \\
\hline Levels & 73.218 & 28.387 & 24.779 & 13.5233173 \\
\hline$\Delta$ & 0.983 & 5.550 & 2.410 & 5.3812593 \\
\hline \multicolumn{5}{|l|}{ Primary Drop-out Rate } \\
\hline Levels & 34.407 & 23.193 & 20.299 & 12.5922302 \\
\hline$\Delta$ & -0.599 & 5.476 & 2.772 & 5.2841724 \\
\hline \multicolumn{5}{|c|}{ Enrollment Rare Primary } \\
\hline Levels (Gross) & 94.742 & 27.174 & 22.645 & 15.3094941 \\
\hline$\Delta$ (Gross) & 0.700 & 4.652 & 1.319 & 4.5264449 \\
\hline Levels (Net) & 79.619 & 19.785 & 17.966 & 9.4942554 \\
\hline$\Delta(\mathrm{Net})$ & 0.656 & 2.651 & 1.600 & 2.4542014 \\
\hline \multicolumn{5}{|c|}{ Enrollment Rare Secondary } \\
\hline Levels (Gross) & 51.938 & 31.583 & 29.577 & 14.8744180 \\
\hline$\Delta$ (Gross) & 1.109 & 2.990 & 1.366 & 2.8403587 \\
\hline Levels (Net) & 53.194 & 27.473 & 26.394 & 11.1531382 \\
\hline$\Delta(\mathrm{Net})$ & 0.944 & 2.844 & 1.861 & 2.5971005 \\
\hline \multicolumn{5}{|l|}{ Duration of Primary } \\
\hline Levels & 5.643 & 0.981 & 0.931 & 0.3197052 \\
\hline$\Delta$ & 0.002 & 0.152 & 0.016 & 0.1526888 \\
\hline Democracy & 0.407 & 0.491 & 0.383 & 0.3274492 \\
\hline Log (GDP. Per cap) & 7.253 & 1.450 & 1.411 & 0.3005501 \\
\hline Urban Population (\%) & 45.727 & 24.264 & 23.450 & 6.3786868 \\
\hline
\end{tabular}


Tabla 3. Estimation Results for Primary and Secondary Education: Linear Fixed-Effect Model.

\begin{tabular}{|c|c|c|c|c|c|c|}
\hline & \multicolumn{4}{|c|}{ Primary Education } & \multicolumn{2}{|c|}{ Secondary Education } \\
\hline & $\begin{array}{c}\text { Completion } \\
\text { Rate }\end{array}$ & $\begin{array}{l}\text { Drop-out } \\
\text { Rate }\end{array}$ & $\begin{array}{c}\text { Gross } \\
\text { Enrollment }\end{array}$ & $\begin{array}{c}\text { Net } \\
\text { Enrollment }\end{array}$ & $\begin{array}{c}\text { Gross } \\
\text { Enrollment }\end{array}$ & $\begin{array}{c}\text { Net } \\
\text { Enrollment }\end{array}$ \\
\hline $\begin{array}{l}\text { Duration of } \\
\text { Primary }\end{array}$ & $-4.868 * * *$ & $4.842 * * *$ & -1.111 & 2.061 & $-4.107 * * *$ & $-6.136 * * *$ \\
\hline & (1.399) & $(1.204)$ & $(2.103)$ & $(1.803)$ & $(1.502)$ & $(1.560)$ \\
\hline $\log (G D P)_{t}$ & $12.474 * * *$ & $-8.034 * * *$ & 0.998 & 2.027 & $10.514 * * *$ & $11.946 * * *$ \\
\hline Democracy & $\begin{array}{c}(3.590) \\
6.310^{* * *} \\
(2.180)\end{array}$ & $\begin{array}{c}(2.757) \\
-5.729 * * * \\
(1.895)\end{array}$ & $\begin{array}{c}(3.770) \\
5.661 * * \\
(2.787)\end{array}$ & $\begin{array}{c}(2.865) \\
2.578 \\
(2.217)\end{array}$ & $\begin{array}{l}(3.374) \\
3.002 * \\
(1.523)\end{array}$ & $\begin{array}{c}(4.075) \\
3.250 \\
(2.719)\end{array}$ \\
\hline $\begin{array}{l}\text { Urban population } \\
(\%)\end{array}$ & $1.040 * * *$ & $-1.205^{* * *}$ & $0.968 * * *$ & $0.883 * * *$ & $1.355^{* * *}$ & $1.004 * * *$ \\
\hline Constant & $\begin{array}{c}(0.190) \\
-38.579 * \\
(20.237)\end{array}$ & $\begin{array}{c}(0.150) \\
118.642 * * * \\
(18.251)\end{array}$ & $\begin{array}{c}(0.203) \\
48.696 * * \\
(24.089)\end{array}$ & $\begin{array}{c}(0.156) \\
10.548 \\
(19.382)\end{array}$ & $\begin{array}{c}(0.130) \\
-61.015^{* * *} \\
((20.669) \\
\end{array}$ & $\begin{array}{c}(0.261) \\
-50.971 * * \\
(21.765)\end{array}$ \\
\hline Sample size & 2397 & 1938 & 3407 & 1914 & 2919 & 942 \\
\hline No. Countries & 121 & 121 & 123 & 122 & 122 & 101 \\
\hline R2 Adj. & 0.484 & 0.512 & 0.239 & 0.367 & 0.628 & 0.664 \\
\hline F-stat & 35.21 & 51.47 & 13.77 & 15.45 & 59.96 & 31.47 \\
\hline
\end{tabular}


Tabla 4. Estimation Results for Primary Education: Effect of Changes in Duration of Primary Education.

\begin{tabular}{|c|c|c|c|c|c|c|c|c|}
\hline & \multicolumn{2}{|c|}{ Completion Rate } & \multicolumn{2}{|c|}{ Drop-out Rate } & \multicolumn{2}{|c|}{ Gross Enrollment } & \multicolumn{2}{|c|}{ Net Enrollment } \\
\hline & $\begin{array}{l}\text { Linear } \\
\text { FE }\end{array}$ & GMM & $\begin{array}{l}\text { Linear } \\
\text { FE }\end{array}$ & GMM & $\begin{array}{l}\text { Linear } \\
\text { FE }\end{array}$ & GMM & $\begin{array}{l}\text { Linear } \\
\text { FE }\end{array}$ & GMM \\
\hline-1 & - & $-0.062 * * *$ & * - & - & $-0.024 * *$ & $*-0.121 * * *$ & $-0.029 * *$ & $* \quad-$ \\
\hline & $\begin{array}{c}0.078 * * * \\
(0.015)\end{array}$ & $(0.003)$ & $\begin{array}{c}0.118 * * * \\
(0.019)\end{array}$ & $\begin{array}{c}* 0.100 * * * \\
(0.002)\end{array}$ & $(0.011)$ & $(0.010)$ & $(0.011)$ & $\begin{array}{c}0.086^{* * *} \\
(0.004)\end{array}$ \\
\hline $\begin{array}{l}\Delta \text { Duration of } \\
\text { Primary }\end{array}$ & -0.838 & $-0.923 * * *$ & $* 2.710 * * *$ & $* 3.603 * * *$ & $*-3.429 * *$ & $*-6.812 * * *$ & -0.457 & $1.028 * * *$ \\
\hline & (1.129) & $(0.111)$ & $(0.868)$ & $(0.191)$ & $(1.382)$ & $(0.185)$ & $(0.652)$ & $(0.099)$ \\
\hline$\Delta \log (G D P)_{t}$ & $3.159 *$ & $10.136 * * *$ & * -4.562 & $7.050 * * *$ & $6.744 * * *$ & $* 15.972 * * *$ & $=1.249$ & $-0.419^{*}$ \\
\hline & (1.664) & $(0.263)$ & (3.857) & $(0.237)$ & $(1.292)$ & $(0.986)$ & $(1.510)$ & $(0.231)$ \\
\hline$\triangle$ Democracy & 0.360 & $0.619 * * *$ & $-3.121 * *$ & k - & 0.487 & $2.149 * * *$ & 0.070 & -0.063 \\
\hline & $(0.749)$ & $(0.208)$ & $(1.457)$ & $(0.051)$ & $(0.323)$ & $(0.220)$ & $(0.510)$ & $(0.235)$ \\
\hline $\begin{array}{l}\Delta \text { Urban } \\
\text { population } \\
(\%)\end{array}$ & -0.271 & $1.824 * * *$ & 0.620 & $\begin{array}{c}- \\
0.198^{* * *}\end{array}$ & -0.145 & $4.100 * * *$ & -0.430 & $0.975^{*} * *$ \\
\hline & $(0.422)$ & $(0.224)$ & $(0.528)$ & $(0.061)$ & $(0.337)$ & $(0.316)$ & $(0.263)$ & $(0.095)$ \\
\hline Constant & $\begin{array}{c}6.570 * * * \\
(1.074) \\
\end{array}$ & $\begin{array}{c}4.362 * * * \\
(0.173)\end{array}$ & $\begin{array}{c}3.356 * * * \\
(0.663)\end{array}$ & $\begin{array}{c}* 3.136 * * * \\
(0.043) \\
\end{array}$ & $\begin{array}{c}* 3.011 * * * \\
(1.091) \\
\end{array}$ & $\begin{array}{c}9.916 * * * \\
(0.996)\end{array}$ & $\begin{array}{c}3.226 * * * \\
(0.918) \\
\end{array}$ & $\begin{array}{c}* 7.979 * * * \\
(0.312) \\
\end{array}$ \\
\hline & 1965 & 1965.00 & 1474 & 1474.00 & 3085 & 3085.00 & 1522 & 1522.00 \\
\hline ountries & 119 & 119.00 & 114 & 114.00 & 123 & 123.00 & 116 & 116.00 \\
\hline R2 Adj. & 0.0414 & & 0.0782 & & 0.0313 & & 0.0121 & \\
\hline F-stat & 6.823 & & 10.16 & & 8.919 & & 2.142 & \\
\hline $\begin{array}{l}\text { Hansen Test } \\
\text { (stat.) }\end{array}$ & & 114.11 & & 109.69 & & 109.15 & & 113.64 \\
\hline $\begin{array}{l}\text { Test AR(1) } \\
\text { (z-stat.) }\end{array}$ & & -3.68 & & -5.07 & & -5.11 & & -4.38 \\
\hline $\begin{array}{l}\text { Test AR(2) } \\
\text { (z-stat.) }\end{array}$ & & 1.11 & & 0.72 & & -0.25 & & 1.24 \\
\hline
\end{tabular}

Notes: The outcome variables are in first differences. This Table reports the results using linear panel fixed-effect model and the GMM estimation method. All specifications include country-fixed effect. Standard errors in parentheses. *** Significant at 1\%, ** Significant at $5 \%, *$ Significant at $10 \%$. 
Tabla 5. Estimation Results for Secondary Education: Effect of Changes in Duration of Primary Education.

\begin{tabular}{lcccc}
\hline & \multicolumn{2}{c}{ Enrollment Rate Secondary (Gross) } & \multicolumn{2}{c}{ Enrollment Rate Secondary (Net) } \\
\cline { 2 - 5 } & Linear Fixed-Effect & GMM & Linear Fixed-Effect & GMM \\
\hline$y_{t-1}$ & $-0.016^{* *}$ & $-0.009^{* * *}$ & $-0.040^{*}$ & $-0.015^{* * *}$ \\
& $(0.007)$ & $(0.002)$ & $(0.020)$ & $(0.001)$ \\
$\Delta$ Duration of Primary & $-1.716^{* *}$ & $-3.440^{* * *}$ & $-3.487^{* *}$ & $-4.449^{* * *}$ \\
& $(0.763)$ & $(0.044)$ & $(1.621)$ & $(0.042)$ \\
$\Delta \log (G D P)^{*} t$ & $4.670^{* * *}$ & $10.413^{* * *}$ & 1.862 & $2.657^{* * *}$ \\
& $(1.244)$ & $(0.100)$ & $(1.821)$ & $(0.013)$ \\
$\Delta$ Democracy & -0.071 & 0.095 & -3.708 & $-5.064^{* * *}$ \\
& $(0.226)$ & $(0.074)$ & $(3.608)$ & $(0.074)$ \\
$\Delta$ Urban population (\%) & 0.199 & $5.694 * * *$ & 0.074 & $0.535^{* * *}$ \\
& $(0.247)$ & $(0.178)$ & $(0.410)$ & $(0.048)$ \\
Constant & $1.657^{* * *}$ & $-1.193 * * *$ & $2.900 * *$ & $1.417 * * *$ \\
& $(0.338)$ & $(0.082)$ & $(1.132)$ & $(0.058)$ \\
\hline Sample size & 2517 & 2517.00 & 685 & 685.00 \\
Number of Countries & 122 & 122.00 & 92 & 92.00 \\
R2 Adj. & 0.0322 & & 0.0830 & \\
F-stat & 5.049 & & 3.581 & 85.41 \\
Hansen Test (stat.) & & 117.71 & & -1.69 \\
Test AR(1) (z-stat.) & & -5.25 & & -1.38 \\
Test AR(2) (z-stat.) & -0.17 & &
\end{tabular}

Notes: The outcomes variables, Gross and Net Enrollment Secondary, are in first differences. This Table reports

the results using linear panel fixed-effect and the GMM. All specifications include country-fixed effect. Standard errors in parentheses. $* * *$ Significant at $1 \%, * *$ Significant at $5 \%, *$ Significant at $10 \%$. 